\title{
A Review of Hearing Conservation Program in Military Services: US Army Hearing Program
}

\author{
Wondo $\mathrm{Na}^{1}$, Woojae $\mathrm{Han}^{2}$ \\ 'Department of Speech Pathology and Audiology, Graduate School, Hallym University, Chuncheon, Korea \\ ${ }^{2}$ Division of Speech Pathology and Audiology, Research Institute of Audiology and Speech Pathology, College of Natural Sciences, \\ Hallym University, Chuncheon, Korea
}

\section{군부대의 청력보존프로그램에 관한 고찰: 미군을 중심으로}

\author{
나 원 도 $^{1}$ 한 우 재 ${ }^{2}$
}

한림대학교 일반대학원 언어병리청각학과 ${ }^{1}$ 한림대학교 자연과학대학 언어청각학부, 청각언어연구소 ${ }^{2}$

\begin{abstract}
Purpose: It is acknowledged that impact of noise in the military should be considered due to exposure to the high intensity levels which occur noise-induced hearing loss and tinnitus. Paradoxically, healthy hearing is a vital role in the performance of a soldier and is important for speech communication during the combat. Methods: This review paper introduces the current US army hearing program including techniques and procedures that govern the prevention of the noise-induced hearing loss in the soldiers and ensure their maximum combat effectiveness. Results: It generally consists of four elements, namely hearing readiness, clinical hearing service, operational hearing service, and hearing conservation. First of all, hearing readiness is to measure the soldier's hearing threshold as a baseline and classify him into appropriate job position. Clinical hearing service is to diagnose a degree of hearing loss and then decide its temporal or permanent loss with detailed clinical measurements. In the operational hearing service, noise abatement strategies and ideal noise levels for engineering controls are included. Hearing conservation is related to identification of hazardous noise and effective use of hearing protector. Conclusion: Like the US army hearing program, we need to serve the hearing conservation program with technical and administrative guidance for preventing the noise-induced hearing loss of young soldiers, in advance, in Korea.
\end{abstract}

Key Words: Noise in military, Army hearing program, Hearing conservation program, Noise-induced hearing loss.

Received: November 30, 2015 / Revised: December 18, 2015 / Accepted: January 5, 2016

Correspondence: Woojae Han, Division of Speech Pathology and Audiology, College of Natural Sciences, Hallym University, 1 Hallimdaehak-gil, Chuncheon 24252, Korea

Tel: +82-33-248-2216 / Fax: +82-33-256-3420 / E-mail: woojaehan@hallym.ac.kr

\section{INTRODUCTION}

소음은 청자가 불쾌감을 느끼는 소리이며, 큰 소음의 노출은 궁극적으로 청력을 손상시킬 수 있다. 현대인들은 소음의 정도 및 노출 시간에 따라 후천적으로 소음성난청(noise-induced hearing loss)을 경험한다. 소음성난청은 주로 3,000 6,000 Hz 의 고주파수 대역에서 청력 역치의 변화가 두드러지고, 소음성 난청을 가진 환자들은 종종 이명을 동반하기도 하며 소음 노출 직후 이통 혹은 이충만감을 호소하기도 한다(Alberti, 1987). 순음청력검사 시 양측성의 청력 손실이 일반적이며, 지속적인 소 음 노출이 단속적인 노출보다 더 큰 손실로 나타난다(Keim, 1970). 소음성난청은 손실 양상의 관점에서 크게 일시적 역치 변동(temporary threshold shift), 영구적 역치변동(permanent threshold shift), 음향성외상(acoustic trauma)의 3가지로 구분 될 수 있다(Department of the Army, 2015). 일시적 역치변동 은 중등도 크기의 소음에 노출되었을 때 일시적인 청력 손실이 나타나지만 수 분에서 수일 내에 걸쳐 청력이 회복되는 것을 일 컫는다(ANSI, 1996). 일시적 역치변동 이후 소음 노출이 추가 적으로 발생되지 않음에도 불구하고 더 이상 청력이 회복되지 않아 난청이 계속되는 현상을 영구적 역치변동이라 한다 (ANSI, 1996). 영구적 역치변동은 때때로 중강도의 소음에 오 랜 기간 지속적으로 노출되어 와우 내 외유모세포와 내유모세 포의 구조물이 서서히 파괴됨으로써 발생되기도 한다. 마지막 으로 음향성외상은 영구적 역치변동의 특별한 형태로서, 강렬 
한 충격음에 의해 고막 및 이소골 등 중이 구조물과 난원창, 정 원창, 혹은 코르티기관 등 내이 구조물은 기계적 손상을 초래 한다(Axelsson \& Hamernik, 1987). 아직까지 일시적 역치변 동과 영구적 역치변동 간의 연관성은 명확하게 밝혀지지 않고 있다(Le Prell et al., 2012). 과도한 소음의 노출은 청력에 영향을 주는 것 이외에도 두통, 불안, 긴장과 같은 신경정신계의 이상, 호 흡이 가빠지고 맥박이 빨리 뛰는 등의 불안정한 순환계 증상, 소 화불량의 소화계 이상 등 동반 증세가 있을 수 있으며 고혈압을 일으킬 수 있다는 보고도 있다(Halford \& Anderson, 1991; Kim, 2002). 이에 따라 US Department of Health and Human Services(1998)에서는 소음성난청 예방을 위하여 $85 \mathrm{dBA}$ 미만 의 소음에 1 일 8 시간 이하의 노출을 권고하고 있다.

소음성난청의 원인으로 산업체 소음과 건설 소음을 대표적 으로 언급할 수 있으며, 교통 소음, 층간 소음, 가전제품 소음 등 일상생활에서 쉽게 접할 수 있는 다양한 환경 소음에의 노 출뿐 아니라(Center for Hearing and Communication, 2014), 군부대에서 사용하는 다양한 무기와 장비들로 인한 군대 내 소음 노출을 들 수 있다. 국외와 달리, 징병제 방식으로 모집하 는 국내의 군제도에서는 20 대 초반의 남성들이 필수적으로 군 복무를 수행하면서 큰 소리에 자주 노출된다(Collée et al., 2011; Lee et al., 1995). 큰 소음의 노출은 적절한 청력보호 장 비를 착용하지 않은 상태에서 개인용 화기를 사용하거나 혹은 포, 탱크와 같은 공용 화기를 사용하는 것이다(Department of the Army, 2015). 이로 인하여 많은 젊은 남성들은 복무 중 혹은 전역 후에 소음성난청이나 소음성이명을 경험하게 된다. 실제로 큰 소음에 노출된 군인이 소음에 노출되지 않은 군인보다 더 큰 청력 손실이 발생되었음을 분석한 연구들이 여럿 있으며 (Bohnker et al., 2002; Collée et al., 2011; Gold et al., 1989; Klockhoff et al., 1986), 화기 거리에 따라 청력 손실과 유의미한
상관관계를 보여준 연구도 있다(Kim, 2012; Hwang \& Park, 2013). 한편, 한국보건사회연구원의 정책보고서 「2014년 장애인 실태조사」에 따르면, 후천적 청각장애 발생시기의 남녀 성비의 차이가 1 2\% 이내로 미비한 다른 연령대와는 달리, 20 29세 의 청각장애 발생률은 남성이 여성보다 $3.6 \%$ 더 높게 나타났다 (Kim et al., 2014). 이를 뒷받침해주는 자료로써, Figure 1의 군 부대에서 사용하는 장비들의 소음 수준을 살펴보면, 군복무 중 군 운송수단의 이용으로 80 130 dBA의 지속적인 소음에 노 출되었거나, 개인용 화기의 사용으로 150 200 dBP의 충동소음 에 노출된 것으로 예상할 수 있겠다. 실제로 Lee et al.(1995)의 조사에 따르면, 군 전역자 중 $10.7 \%$ 가 소음성난청의 초기 형태 인 C-5 dip의 청력도를 보여 주었고, Henselman et al.(1995)의 연구 결과 또한 군인의 소음 노출과 청력 손실에 직접적인 관계 가 있음을 보여주었다. 점차 군복무 중 고강도의 소음 노출과 그로 인한 청각적 피해에 대한 인식이 높아지면서, 국가인권위 원회는 2012년 「군복무로 인한 이명 피해 예방 및 피해자 구제 방안 마련」을 보도하였다. 보도 자료에 따르면 미국, 캐나다, 호 주 등 국외의 전역 군인 중 약 $9.5 \%$ 는 소음성이명으로 진단되 는 것에 비해 국내에서는 군 전역자 중 겨우 309명만이 이명장 애로 집계되어 상당수의 군 이명 피해자가 더 있을 것으로 추 정되며, 전문가들은 이에 대한 구체적인 구제 방안이 마련되어 야 한다고 주장하고 있다(Kim et al., 2012). 더불어 군복무로 인한 청력 손실 및 이명 피해자가 꾸준히 발생되고 있다는 점 에서 군인들의 소음 노출 측정 평가, 주기적 청력검사 실시, 청 력보호장비의 올바른 착용을 주요 내용으로 하는 예방적 차원 의 청력보존프로그램의 필요성이 점차 대두되고 있다.

본 종설 논문에서는 2015년 1월 발표된 'Department of the Army Pamphlet 40-501」를 분석하여 현재 미군에서 시행 중 인 군인들을 위한 청력보존프로그램을 살펴보고자 한다(De-

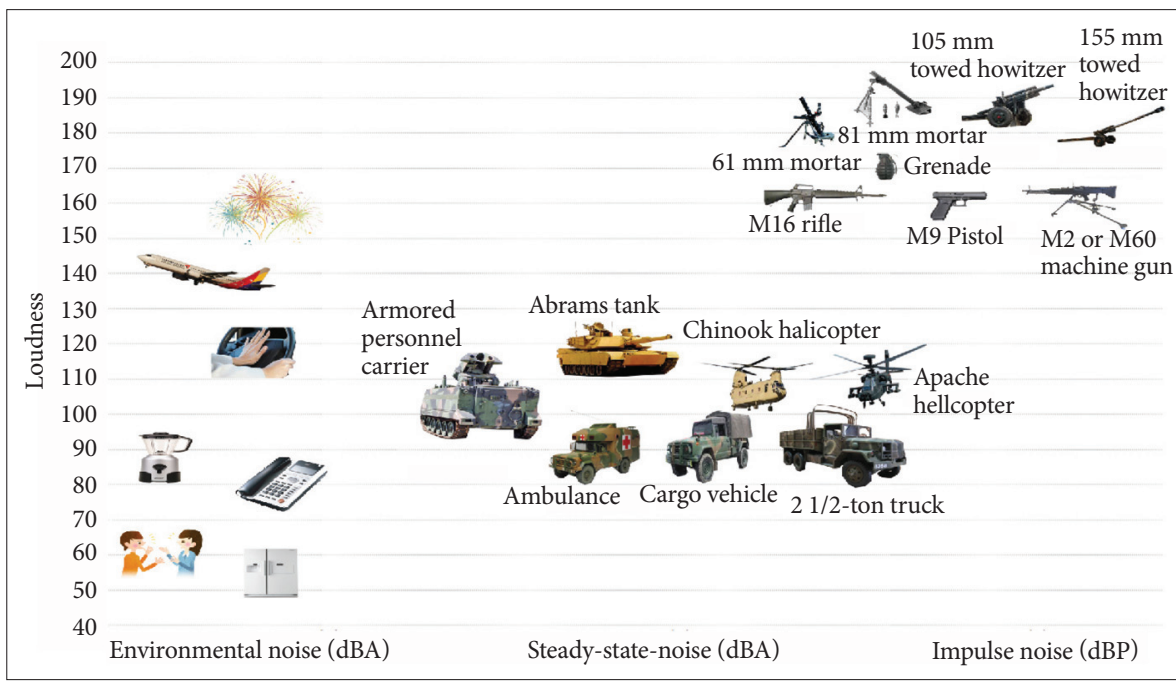

Figure 1. Graphical display for comparison of various environmental noises (left) and noise types occurred in military services such as steady-statenoise (middle) and impulse noise (right) as a function of loudness. Source references from US army center for health promotion and preventive medicine, center for hearing aid communication, and national noise information system. 
partment of the Army, 2015). 미군청력프로그램(army hearing program)은 군인과 군무원의 소음성난청을 예방하기 위한 과 정과 정책 및 전략을 자세히 제공하고 있으며, 청력준비(hearing readiness), 임상적 청력서비스(clinical hearing service), 군 사작전 중 청력서비스(operational hearing service), 청력보존 (hearing conservation)의 4가지 요소를 포함하고 있다. 첫째, 청력준비는 군인이 직종별 업무 시 요구되는 청력을 가지고 있 는지 확인한다. 청력준비의 주된 목적은 초기의 청력 변화를 식별하고, 청력 손실을 예방하기 위하여 교육 실시, 개별 상담 을 제공하는 것이다. 둘째, 임상적 청력서비스는 발생한 난청의 원인과 정도를 확인하고 군인의 기초체력과 결부하여 최종 진 단을 내리는 것이다. 특히, 위험한 소음에 노출되는 군인 및 군 무원에 대한 임상 서비스는 난청과의 업무 관련성을 판단하기 위함이며, 난청의 정도와 원인을 임상적으로 판별한 후, 치료 및 관리를 계획한다. 해당 군인들의 수술적 치료, 보청기 처방, 청각 보조 장치, 청능 재활, 이명 관리뿐 아니라, 소음이 적은 곳으로 재배치 등 전반적인 모니터링을 실시한다. 셋째, 군사작 전 중 청력서비스는 작전 중 발생될 소음성난청을 예방하거나 최소화하는 데 초점을 맞춘다. 예를 들어, 군인의 작전 능력을 증진시킬 수 있도록 도와주는 전술 통신 및 보호 시스템(tactical communications and protective system)은 저강도의 소리 를 증폭하는 동시에 위험한 충격 소음으로부터 귀를 보호하면 서 무선 통신과의 결합이 용이하도록 설계되었다. 따라서 소음 측정 및 소음 저감 대책을 세우고, 군사 작전 시 잡음을 줄이고 원활한 의사소통을 가능케 하는 통신기술의 개선은 물론, 소 음성난청을 예방하기 위해 설계된 전문 청각보호장비의 올바 른 사용에 초점을 맞춘다. 마지막으로 청력보존은 수년 간 군 청력프로그램에서 소음성난청을 예방하기 위하여 위험한 소음 의 평가 및 확인과 소음 수준에 따른 적절한 청력보호장비의 착용에 대한 노력을 보여주었다. 이러한 내용을 바탕으로 본문 에서는 군 청력프로그램의 4가지 구성요소를 자세히 소개하고, 궁극적으로는 국내를 포함하여 군부대에서 발생될 수 있는 소 음성난청에 대해 좀 더 제도적으로 예방할 수 있는 안내서로 사용하고자 한다.

\section{HEARING READINESS}

청력준비는 군인의 성공적인 군사 작전 수행 시 요구되는 청 력 확인 절차이다. 따라서 청력의 초기변화를 확인하여 군인들 의 일시적/영구적 난청의 발생을 최소화하고 안전하게 훈련을 받을 수 있는 여건을 제공한다. 만약 군인이 청력준비 과정 없이 난청 여부를 확인하지 못하고 전쟁에 참여하게 된다면, 적군의 위치를 정확하게 인식하기 어렵고, 아군과의 제한된 의사소통
으로 인해 부정적인 결과를 초래할 것이다. 즉, 군인의 청력 손 실은 상사의 명령, 무선통신을 통한 의사소통 이해, 위험한 소 리 발생지로부터 거리의 정확한 인식을 위한 청각적 정보처리 능력을 결함시켜 심각한 사고 발생률을 증가시키고 부대를 위 태롭게 할 수 있다. 이러한 결과를 초래하지 않기 위해 사전에 청력준비과정을 통하여 군인들의 청력 관리가 필수적이다.

\section{Monitoring audiometry}

미 연방 직업안전 환경보건국의 건강준비시스템을 근거로 청 력검사를 모니터링 하는 것이 청력준비의 핵심구성이다. 모든 군인은 유해소음에 노출되기 전 가장 먼저 기준청력검사를 받 아야 하며, 일시적 역치변동의 발생을 대비하여 군인은 기준청력 검사를 받기 최소 14 시간 전 반드시 소음 노출을 피해야 한다.

청력준비 과정 중 정확한 장비를 갖추는 것이 우선 시 된다. 자동화된 여러 대의 청력검사기기로 동시에 검사를 실시하여 청력검사 결과의 최종 청력도를 완성하고 추적관리한다. 청력 검사기기의 정상적인 기능 및 결과의 높은 신뢰성을 위해 미국 표준협회(American National Standards Institute, ANSI) 기준 에 부합되게 검사기기의 전기 음향적 보정을 연 1회 실시하여 야 한다. 또한 장비 사용 하루 전 사용자 매뉴얼을 참고하여 작 동 기능에 대한 생리적 교정 및 기능 검사를 체크하도록 한다.

청력검사가 이루어지는 장소는 500, 1,000, 2,000, 4,000, $8,000 \mathrm{~Hz}$ 에서 각각 $27,29,34,39,41 \mathrm{~dB}$ SPL의 배경소음수준 을 초과하지 않아야 한다. 설치된 청력검사 부스는 검사자가 편 안하게 검사를 받을 수 있도록 적절한 환기시스템을 제공해야 하지만, 환기는 허용소음수준 이하에서만 사용될 수 있다. 청 력검사 부스 내부에 페인트 도색을 할 경우, 금속 인테리어 페 인팅은 소음감소 효과를 간섭할 수 있으므로 자제한다. 부스의 재배치 혹은 부스 내부 및 외부의 유의미한 소음 발생 시 재보 정이 필수적이다.

검사에 필요한 기술은 육군·해군·공군의 청력관리프로그 램을 통하여 훈련되거나, 직업청력보존을 관장하는 의회에서 승인된 교육과정을 이수한 전문가만이 청각검사 모니터링 과정 에 참여할 수 있다.

\section{Medical protection system}

청력준비의 의학적 보호시스템은 추적관리를 포함하여 개인 및 부대 단위의 청력준비 모니터링이다. 미 연방 직업안전 환경 보건국에서 규정하는 청력보존을 위한 청력도는 정보처리기관 에서 다루기 때문에, 의학적 보호시스템은 정보처리기관으로부 터 자료를 받는다. 검사 자료를 사용하되, 청력준비 분류로 상 태를 구분한다. 분류는 4단계로 구분되며, $\mathrm{HRC}-1$ 과 $\mathrm{HRC}-2$ 는 배치상태를, $\mathrm{HRC}-3$ 과 $\mathrm{HRC}-4$ 는 추후 임상적 검사가 필요한 
상태이다(Table 1). 미 연방 직업안전 환경보건국의 청력보존 자 료 절차에 따라 의학적 보호시스템 데이터입력 시 수기로 작성 하고, 입력 후 즉시 청력준비 분류를 업데이트하고, 청력 데이 터가 만기될 때까지 수기로 작성된 데이터를 의학적 보호시스 템에 보관한다. 수기로 작성된 모든 데이터는 중복기재 가능하 며, 청력준비분류 상태가 업데이트 되었을 때, 의학적 보호시스 템과 직업안전 환경보건국 청력보존에서 모두 검사 데이터를 수정관리한다. 의학적 보호시스템의 청력프로그램 관리자는 청력준비 상태를 의학적 보호시스템의 청력준비 기능을 통해 서 모니터링하고, 추적할 수 있으며, 청력에 관한 자세한 정보 를 제공한다. 청력프로그램 관리자는 역치의 유의미한 변화가 있는 군인을 추적 및 모니터링 해야 한다.

\section{Medical protection system training}

의학적 보호시스템에서는 군인이 적절한 기술을 사용할 수 있도록 훈련을 제공한다. 훈련은 청력프로그램 관리자가 실시 하거나, 지정된 의학적 보호시스템의 대표가 할 수 있다. 의료 인력이 추가로 필요한 경우, 의학적 보호시스템에서 제공하는 훈련을 받아야 하며, 수업 일정은 의학적 보호시스템의 코디네 이터부터 받을 수 있다.

\section{Hearing readiness classification}

군인은 미 연방 직업안전 환경보건국의 청력보존에서 12개월

Table 1. Criteria of $\mathrm{H}-1, \mathrm{H}-2, \mathrm{H}-3$, and $\mathrm{H}-4$ classification

H-1 Normal hearing or anything above average

H-2 Mild hearing loss

H-3 Moderate hearing loss

H-4 Moderate-to-severe or below (i.e., severe and profound hearing loss)

Table 2. Medical protection system and army hearing program classification

1 PROFIS $-2215^{1)}, 2216^{2)}$ within past 12 months on record and hearing test is $\mathrm{H}-1$.

2 H-1 Profile, H-2 Profile (evaluated and assigned on DA Form 3349), H-3 Profile (evaluated and assigned on DA Form 3349 , MAR2 (MOS administrative retention review) are completed.

$3 \mathrm{~A} \quad \mathrm{H}-2$ or $\mathrm{H}-3$ and full evaluation by audiologists are not completed or documented.

3B H-2 or H-3 and full evaluation are completed but DA Form 3349 are not completed.

3C $\mathrm{H}-3$ profile and all items in $3 \mathrm{~A}$ and $3 \mathrm{~B}$ are completed but MAR2 are not completed.

3D $\mathrm{H}-4$ profile does not meet retention standards with hearing aids.

3E Threshold of the last audiogram is greater than $\mathrm{H}-2$ and no hearing aid has been issued.

4 Hearing readiness classification unknown. No hearing test and DD Form 2215/2216 for last 12 months or No DD Form 2215 or 2216 on record.

4A Most recent DOEHRS-HC audiogram of the solider is more than 12 months old.

4B The solider has received a DOEHRS-HC audiogram within the last 12 months. However, a significant threshold shift (STS) has been identified and a follow-up hearing test is required.

4C The STS is demonstrated and the solider does not complete follow-up testing within 90-days of the periodic hearing test.

1) DD Form 2215 is a document for reference audiogram

2) DD Form 2216 is a document for hearing conservation data
안에 청력도를 받아야 한다. 청력준비를 위한 분류는 Table 1과 즌 정상 청력을, $\mathrm{H} 2, \mathrm{H} 3, \mathrm{H} 4$ 는 각각 경도 난청, 중도

Table 1 의 청력준비 분류와 연관되어 분류되는 의학적 보호 시스템은 Table 2 와 같다. 즉, Table 2 의 1 은 보청기를 착용하지 않은 청력이 양귀에서 $\mathrm{H}-1$ 이며, 미군 규정 40-501에 부합해야 한다. 특별한 조치는 필요치 않다. Table 2의 2는 보청기를 착 용하지 않은 청력이 $\mathrm{H}-2, \mathrm{H}-3$ 이다. 중이 질병이나 의학적인 병 변이 없는 좋은 쪽 귀에서 최근 국방부문서 3349(신체 관련 프 로파일)가 $\mathrm{H}-2, \mathrm{H}-3$ 의 상태이고, 소음속 말인지 검사와 주특 관리 역량 확인도 완료한 상태이다. 필요시 보청기와 6 개월 사용량의 배터리를 지급받을 수 있다. 추후 다른 조치는 필요 Table 2의 3은 보청기를 착용하지 않은 청력이 $\mathrm{H}-2, \mathrm{H}-3$ 에 해당되어 좀 더 자세한 임상청각적 평가가 필요하며, 국방부 전 $\mathrm{H}-2, \mathrm{H}-3$ 의 상태로 기록되어 있다. $\mathrm{H}-3$ 의 청력 실을 가진 모든 군인은 소음속 말지각 검사와 주특기 관리 적으로 배치되기 위해, 진단평가, 프로파일 작성, 주특기 관리 역 량 확인이 청능사에게 의뢰되어야 한다. 청력준비분류 $3 \mathrm{E}$ 에 지정 을 배치를 권장할 수 없으며, 보청기 적합과 6 개월간 사 청력보존의 청력도가 요구된다. 청력준비분류 $4 \mathrm{~B}$ 는 배치를 권 장할 수 없으며, 정기적인 검사에서 역치의 유의미한 변동이 발 견되었기 때문에 재검사가 필요하다. 재검사는 90 일 이내에 이 
루어져야 한다. 마지막으로, 청력준비분류 $4 \mathrm{~B}$ 혹은 $4 \mathrm{C}$ 는 재검 사된 청력도가 완료될 때까지 배치하지 않는다.

\section{Hearing readiness enrollment and requirements for soldiers}

어떤 무기를 처음 사용하기 전이나, 유해 소음 노출되기 전 단계, 진입 훈련 또는 기본 임원 리더 과정에서 모든 군인은 청 력검사(국방부 지시 문서 2215)를 받게 된다. 편성 및 장비표에 해당되는 모든 군인은 매년 정기적으로 청력검사를 받는다. 인 원 및 장비배당표에 해당되는 군인도 청력검사를 받으며, 유해 한 소음이 있는 지정된 영역에서 근무하는 군인 역시 청력검사 를 받는다.

배치된 모든 군인은 배치 12 개월 이내에 사전 실시한 미 연방 직업 안전국 환경보건국의 청력검사 결과가 필요하다. 재배치된 군인은 해외비상작전을 위한 Army Personnel Policy Guidance 에 의거하여 최종 청력도를 완성해야 한다. 기준청력도는 배치 전 수행되어야 하며 기준청력에 미치지 못하는 경우, 주기적으 로 검사 후 재배치 실시한다. 추가로 미 주 방위군이나 예비역 이 청력상태를 확인하고 임상청각적 평가로 인한 청력치료서비 스를 받기를 원하면, 동원사이트에 접속하여 신청가능하다. 현 역군인은 자대배치 후 청력평가와 미 연방 직업 안전국 환경보건 국에서 청력도를 받으며, 6 개월 이내에 청력평가를 받을 것이다.

\section{Hearing health education}

청력프로그램 관리자는 소음에 노출된 모든 사람들에게 청 력건강교육을 제공해야 한다. 매년 청력건강교육 브리핑을 실시 하여 청력준비 모니터링, 이어플러그의 수리, 군인 청력준비를 실시한다. 부대 내 청력프로그램을 담당하는 장교는 부대원의 심리 건강 교육 요구 사항을 추적하고, 연간 교육의 완성을 위 한 문서를 유지해야 한다. 매년 실시하는 청력건강교육은 청력 검사 시 소음이 청력에 미치는 영향, 이어플러그와 같은 소음방 지의 목적과 장-단점, 다양한 타입의 감쇠와 보청기 선택, 피팅, 사용, 관리에 관한 내용을 제공해야 하며, 청력검사의 목적과 결과를 설명해야 한다. 군인을 위한 추가적인 청력건강교육은 군 청력프로그램의 개요, 임무완수에 있어서 청력의 중요성, 청 력 손실의 원리, 의사소통이 전투 임무에 미치는 영향, 청력보 호장비의 선택, 피팅, 사용 및 관리, 청력검사를 포함하여 청력 준비 모니터링의 목적, 청력 손실 방지 전략, 대안, 소음 감시 및 완화 전략의 내용을 포함해야 한다.

\section{Hearing protection}

군인과 배치될 수 있는 군무원의 청력준비 필요품인 이어플 러그 역시 매년 보정해야 하며, 여분의 이어플러그를 재피팅을
한다. 수리 및 보정을 검사하는 동안 추가로 청력준비 모니터 링, 연간 부대 청력 건강 교육 브리핑, 군인 청력준비 과정이 수 행되어야 한다. 의사소통전략과 청력 보호 시스템과 같은 청력 보호 훈련에 관한 추가적인 정보는 청력프로그램 관리자로부 터 얻을 수 있다.

\section{Tinnitus screening}

군인들은 정기적으로 이명 선별검사를 받고, 청능사 및 이비 인후과 전문의는 그 결과를 바탕으로 이명의 존재여부에 대해 기록하고 문서화한다.

\section{CLINICAL HEARING SERVICES}

임상적 청력서비스는 청력 손실의 영향, 원인, 정도로 시작된 다. 군인 또는 군무원의 청력 손실이 확인되면, 청능사는 치료 및 관리를 계획하고 임상평가 및 치료, 난청예방교육 등에 대한 내용을 제공한다. 또한, 임상적 혹은 수술적 치료, 보청기 및 청 각보조장치의 추천, 청능 재활, 이명 평가 및 모니터링을 포함 한다.

\section{Referral for diagnosis and disposition}

특정 기준이 충족될 때 미 연방 직업안전 환경보건국의 청력 보존은 자동적으로 권장사항을 추천한다. 또한 저주파수 혹은 고주파수의 청력 손실, 양이의 청력 손실 차이 때문에 차폐가 필요할 때, 비대칭의 청력 손실의 경우 중 하나 혹은 둘 이상 해당될 때 진단을 위한 청력검사를 의뢰한다.

진단을 위한 청력 의뢰는 청력의 영구적인 변화를 확인하고, 청력 손실의 원인과 유형을 결정해야 하며, 필요시 이명평가를 실시해야 한다. 의뢰가 결정된 후 30 일 이내에 해당 검사가 완 료되어야 한다. 고막의 팽창, 중이염 의심, 고막 천공이 있는 경 우에도 환자를 의뢰해야 하며, 환자의 병리적 문제가 해결되고 청력 손실이 해결되거나, 진찰에 대한 의뢰가 여전히 필요한 경 우 후속청력검사를 실시해야 한다. 갑작스러운 돌발성난청으로 진찰 또는 의심되는 경우, 청능사 혹은 이비인후과 전문의에게 즉시 연락해야 한다.

\section{Diagnostic audiometry}

청능사, 이비인후과 전문의 또는 의사만이 소음성난청을 진 단할 수 있는 전문 관리자로 인정된다. 이들은 진단에 있어 개 인의 의료 기록의 조사, 청력검사 검토, 청력 진단 평가 등 합리 적인 방법을 사용해야 한다. 청력 진단 평가는 기도 및 골도 순 음청력검사(필요시 차폐 실시), 어음인지역치 검사, 어음인지도 검사, 고막운동도의 중이검사, 음향반사역치 검사, 이음향방사 
검사, 전정기능 검사, 이명 검사를 실시한다. Table 1 의 H-3 해 당 군인들은 반드시 소음속 말지각 검사를 받아야 하며 필요 시 반복해야 한다.

\section{Hearing profile calculation}

앞서 명시한 대로, 청력상태는 $\mathrm{H}-1, \mathrm{H}-2, \mathrm{H}-3, \mathrm{H}-4$ 의 4가지 로 분류한다(Table 1). 미 연방 직업안전 환경보건국의 청력보 존 청력도에 기초하여 계획하며, 청능사 혹은 전문의만 프로파 일을 분류할 수 있다. 청력 프로파일 가이드라인에 대한 추가 정보는 미군 규정 40-501에서 얻을 수 있다(Department of the Army Pamphlet 40-501 참조). 전반적인 청력 평가는 청력 프로파일의 초기에 필요하다.

\section{Temporary and permanent hearing profiles}

청력 프로파일은 진단적 청력평가 결과에 기초해야 하며, 기 도 순음청력검사의 결과만으로는 영구적인 청력상태를 결정할 수 없다. 청능사와 전문의만이 영구적인 청력상태를 기록할 수 있으며 청력 정보는 e-profile 응용프로그램에서 사용될 수 있 다. 일시적인 청력 손실의 상태가 나아지지 않는다면, 손실은 영구적으로 간주된다. 일시적 혹은 영구적인 청력상태들은 주 로 $\mathrm{H}-2$ 부터 해당되고, 청능사들이 결정한다. $\mathrm{H}-2$ 보다 더 큰 영 구적 상태의 경우, 전문의와 함께 결론짓도록 한다.

\section{E-Profile}

E-Profile 응용프로그램은 자료수집 가이드라인을 따르며, 미군 규정 40-501과 주특기 관리 역량 확인 정책에서 찾을 수 있다. 미군 규정 40-501에 따라, 소음속 말지각 검사 점수는 eprofile에 주석으로 덧붙어져야 한다.

\section{Military occupational specialty administrative retention review}

주특기 관리 역량 확인은 의료 유지 기준들을 충족하지만 추가로 요구되는 군사적 주특기를 이행할 수 없는 군인에 대한 관리이다. 주특기 관리 역량 확인은 군인이 주특기에서 재교육 이 필요한지 또는 다른 주된 주특기에 재배치 될 것인지를 결정 할 때 사용된다. 주특기 기준들을 충족하지 못하고 재배치가 필요한 군인들은 신체장애평가 시스템에 의뢰된다. 주특기 관 리 역량 확인 과정은 국방부문서 3349와 영구적 청력 프로파 일의 관리 검토에 의해 수행된다. E-profile 주특기 관리 역량 확인은 자료 수집과정과 유사하게 워크플로우 중심의 접근방 법, 군인의 위치에 기반한 주특기 관리 역량 확인 프로세스 관 리자에 대한 프로파일의 자동분배, 군인을 위한 추적 도구들 과 검토 과정에서 사용할 수 있는 체크리스트 등을 포함한다.
주특기 관리 역량 확인은 군인에 대한 주특기의 유지, 다른 주 특기로 재배치, 신체장애평가 시스템으로 의뢰와 같은 3 가지 결과들 중 한 가지로 결정된다.

\section{OPERATING HEARING SERVICES}

군사작전 시 청력서비스의 주된 목표는 군사작전 중 군인들 의 소음성난청을 예방하는 것이다. 정상 청력을 유지하는 것은 특히 위험하거나 성가신 소음들이 있는 작전 환경 시 효과적인 의사소통에 필수적이다. 최첨단 기술 전장에 배치된 청력 손실 이 있는 장교는 효과적인 의사소통을 할 수 없어 최상의 수행 력을 보이는 데 한계가 있다. 한편, 군사작전 시 정상 청력을 가 진 군인도 폭발이나 다른 소음 노출의 결과로 인해 순식간에 청력이 손실될 수 있고, 즉각적인 청력 손상은 상황 인지 능력 을 감소시켜 전투력을 떨어뜨린다. 따라서 통신 능력에서 위험한 소음의 영향을 줄이는 전략 청력 보호 시스템뿐 아니라, 작전 시 발생되는 소음 평가 및 소음 저감 전략에 초점을 맞춘 군사 청력 가이드라인을 제공하는 것이 중요하다.

\section{Nuisance noise}

성가신 소음은 통신을 방해하거나 편안한 숙면을 방해하는 등 불필요하게 생성된 소리를 뜻한다. 귀는 군인이 깨어 있거나 혹은 잠들어 있는 동안에도 지속적으로 환경음을 처리하는 중 요한 감각 기관이며 경고 시스템이다. 허용 가능한 소음 수준 은 작업 환경에 따라 다르다. 예를 들어, 허용 가능한 배경 소 음이 잠자는 텐트에서보다 군사 작전 본부에서 크기 때문에 작 업별 허용 가능한 소음 레벨을 달리 해야 되며, 그 기준을 엄격 히 따르는 것이 중요하다.

\section{Non-auditory effects of noise}

비청각적으로 소음은 군인 및 군무원에게 스트레스와 피로 를 발생시킨다. 성가신 소음은 짜증나게 하거나 화나게 하고, 잠을 깨우고, 효율성을 감소시켜 좌절하게 하고, 우울증을 유 도할 뿐만 아니라, 의사소통과 집중력을 방해하기 때문에 군인 들의 임무 수행에 있어 전반적으로 부정적인 영향을 끼친다. 따 라서 대면 브리핑 또는 무선 통신을 포함하여 통신의 용이성을 위해 청력을 보존하는 것은 비청각적으로 스트레스를 낮추고 군인들의 운영 효율성을 증가시킨다. 더불어 충분한 휴식 및 수 면 주기를 유지하는 것은 면역 시스템의 능력을 증가시켜 질병 을 이겨내고, 예리한 인식 능력의 유지 및 높은 정신력과 운동 능력을 유지할 수 있다. 


\section{Operational noise hazard assessments}

청력프로그램 관리자는 군부대에서 발생되는 소음의 위험도 를 평가하고 성가신 소음 평가에 대한 교육을 지원한다. 군대 청력프로그램 담당자들은 소음 평가 및 저감 전략에 대해 교 육을 받고, 청력프로그램 관리자들의 권장 사항을 구현할 책임 이 있으며, 장교로부터 지원을 요청할 수 있다. 본부의 전술작 전 환경, 수면 및 휴식 장소, 식당 시설을 포함한 모든 환경은 소음 평가에 해당되며, 소음 감소를 위한 전략들이 구현되어야 한다.

\section{Basic noise abatement strategies}

작전 시 성가신 소음으로부터 완화시키기 위한 기본 전략들 은 소음원으로부터 멀어지는 것이다. 가능하면 막사나, 기지로 부터 발전기를 멀리 떨어트려 두고, 에어컨 실외기는 연장호스 를 사용하여 멀리 두어야 한다. 소음원으로부터 거리가 두 배가 될 때 인간의 전체 소음 수준은 유의미하게 감소됨을 인식해야 한다. 즉, 역제곱법칙은 소음원으로부터의 $6 \mathrm{~dB}$ 감소시킨다. 소 음원을 멀리할 수 없는 상황에서, 소음과 가까이 있을 경우, 모 래주머니를 소음원 근처에 두어 발생된 소음을 최대한 감쇠시 켜야 한다. 가능하다면 추가로 소리를 감쇠시킬 수 있는 장애 물을 설치하는데, 방음벽을 설치하는 것도 하나의 방법이 될 수 있다. 결론적으로 소음원과 거리를 최대한 멀리할 수 있도 록 하고, 소음감쇠를 할 수 있는 장애물을 설치해야 한다. 소음 상황에서 이어플러그는 좀 더 편하게 휴식과 수면을 취할 수 있도록 도와주고, 충분한 휴식을 통해 군인의 최대 능력을 성 취할 수 있다. 청력보호구장비의 사용 역시 소음을 줄일 수 있 는 해결책이 될 수 있다.

\section{Ideal noise levels}

전술작전본부의 경우, 공통 영역에서의 이상적인 소음 수준 은 최대 $15 \mathrm{ft}$ 거리에서 편안하게 통신할 수 있는 능력을 유지 할 수 있도록 $55 \mathrm{~dB}$ 를 초과하지 말아야 한다. 수면을 위한 이 상적인 소음 수준은 $40 \mathrm{~dB}$ 를 초과해서는 안 된다. 소음이 많은 환경에서 차폐나 비교적 낮은 수준의 광대역 소음은 잡음의 부 정적 효과를 제거하기 위해 요구될 수 있다. 소음은 항공기 소 리, 화물을 싣고 내리는 차량 소리 등 종류에 따라 거슬릴 수 있으며 간헐적 소음으로 다양성을 가진다. 음압은 엔진의 거리 에 영향을 받는다. 예를 들어, $\mathrm{UH}-60$ 헬기가 $150 \mathrm{yd}$ 떨어진 곳 에서 착륙한다면 $150 \mathrm{yd}$ 떨어진 텐트 내부에 들어오는 소음수 준은 $90 \mathrm{~dB}$ 일 것이다. 이 소음은 텐트에서 휴식과 수면을 취하 는 군인을 방해하기에 충분히 크다.

\section{Engineering controls}

공학적 통제는 배치된 군인이나 군무원들의 귀에 도달하는 소음의 양을 감소시킴으로써 소음 노출을 줄일 수 있도록 장비 를 종합적으로 설계하는 방법이다. 이러한 통제는 소음원이나 소음 경로에서 장비의 수정, 교체, 또는 관련된 물리적 변화를 모두 포함한다. 공학적 관리의 범위는 단순한 것에서부터 복잡 한 것으로 매우 광범위하며 조용한 기계를 디자인하는 것까지 포함된다. 보다 복잡한 공학적 장비는 산업위생전문가의 컨설 팅을 필요로 한다.

\section{HEARING CONSERVATION}

과거에 주로 직업적 또는 산업적 소음 노출로부터 개개인의 청력을 보호하기 위해 초점을 맞추어 오던 부분이 군인들의 청 력 손실을 예방하기 위해 새롭게 디자인되었다. 군대 내에서의 청력보존의 필수 요소는 위험한 소음의 식별 및 평가, 공학적 제어, 청력보호, 청력감시, 보건교육, 보존프로그램의 적절성 평 가를 포함하고 있다.

\section{Hazard noise identification}

산업위생프로그램의 일환으로, 산업위생전문가는 위험한 소 음을 확인하고 평가할 책임이 있다.

\section{Hazard noise criteria}

소음은 일반적인 산업 보건 위험 중 하나이며, 유해 소음은 산업체의 제조 환경뿐 아니라 군사 작전 환경에서도 일반적이 다. 보호되지 않은 소음 노출의 결과로 영구적인 청력 손실이 초래될 수 있다. 따라서 해로운 소음의 기준을 정하고, 이에 대 한 체계적인 보호가 필요하다. 위험한 소음의 네 가지 주요 유형 으로는 지속적 소음, 충격소음, 초음파, 폭발음의 높은 압력이다. 각 소음별 위험 수준은 상황별로 다르게 관리되어야 한다.

\section{Posting of hazardous noise areas and equipment}

모든 위험 잡음 영역과 항목이 간판을 사용하여 시각적으로 표기하여야 한다. 고강도의 소음 노출 및 청력보호구 착용의 필요성, 관련 위험에 대한 경고, 유해 소음 지역 등의 표기가 중 요하다. 미국산업안전보건청은 위험 표지판에 사용되는 빨강, 검정, 하얀 색상이 ANSI Z535.1의 안전 색상 기준에 부합되도 록 사용하며, 표준 색상은 노란색 배경, 검은색 패널, 노란색 문 자로 작성하도록 지정하고 있다. 주의 표지판 영역에 게시하는 것은 잠재적인 위험 요소나 위험한 행동에 대한 주의 사항에 대 해 경고한다. 예를 들어, 85 100 dB의 소음원의 입구 또는 유해 소음지역 주변에 적절한 주의를 요하는 기호를 표기하며, 100 
$\mathrm{dB}$ 이상의 소음원 입구 혹은 소음원 주변에는 위험 영역을 명 확히 표시해야 한다.

보다 자세한 유해 소음 정도는 아래와 같은 표기를 따른다.

- 85 100 dB(A)의 장비는 '적절한 주의를 요한다'는 라벨 또 는 태그를 표기한다.

- $100 \mathrm{~dB}(\mathrm{~A})$ 이상의 장비는 '유해하다'는 것을 나타내는 라 벨 또는 태그를 표기한다.

- $140 \mathrm{~dB}(\mathrm{P})$ 보다 큰 소리의 장비는 '발사 범위 및 피해가 가 는 모든 영역'에 위험 표지판을 설치한다.

- 108 165 dB(P)를 초과하는 유해 소음 지역 또는 장비의 경우, 보다 엄격한 절차에 따라 미국국토안보부의 표기 기 준을 따른다.

미국국토안보부는 노출한계수준을 부과할지 여부를 지정하 고, 건강위험 평가보고서에 정의를 하거나 또는 관여하는 장비 의 특정 부분에 대한 청력 보호 요구 사항을 기술 가이드 및 사용자의 메뉴얼에 명시할 수 있다.

\section{Hearing protector requirements}

유해 소음 수준에서 무기를 사용하거나 혹은 장비, 차량, 항 공기 주변에서 작업할 때 군인 및 군무원은 Table 3 의 기준에 서 적절한 청력보호장비를 착용해야 한다.

전투에서 군인들이 무기를 발사하거나 또는 전술 차량 및 항 공기 탑승 시 적절한 청력보호장비를 착용하여 일시적 또는 영 구적 역치변동을 예방해야 한다.

\section{Hearing protection}

잠재적으로 위험한 소음 지역에 있는 모든 군인 및 군무원은

Table 3. Criteria of hearing protector selection according to a type and level of noise

\begin{tabular}{|c|c|}
\hline & Type of hearing protection \\
\hline \multicolumn{2}{|l|}{ Steady-state noise } \\
\hline 85-103 dB TWA & Earplugs or earmuffs \\
\hline $103-108$ dB TWA & $\begin{array}{l}\text { Either earplugs }+ \text { helmet or earplugs + } \\
\text { noise muffs }\end{array}$ \\
\hline \multicolumn{2}{|l|}{ Impulse noise } \\
\hline $140-165 \mathrm{dBP}$ & Use of single hearing protection \\
\hline$>165 \mathrm{dBP}$ & Use of double hearing protection \\
\hline
\end{tabular}

TWA: time-weight average
위험한 소음으로부터 청력을 보호하기 위해 청력보호장비를 착용해야 한다. 보청기의 사용은 소음을 감소시키거나 청력 보 호를 하지 않으므로, 위험한 소음환경에서는 착용하지 않는 것 이 바람직하다. 또한 MP3와 같은 개인 장비 또한 소음 환경 시 착용하지 않는다. 청력보호장비란 귀마개, 헤드폰, 이어플러그, 소음감쇠 헬멧, 의사소통전략과 청력보호 시스템, 또는 이들의 조합을 말한다. 특정상의 이유로 금기되지 않는 한 승인된 목 록에서 청력보호장비를 선택하고 전투 환경에서 자신이 능력 을 높이기 위해 훈련 기간 동안에도 보호구를 착용하여 익숙 해지도록 한다.

\section{Hearing protector types}

청력보호장비의 유형은 아래와 같이 크게 4 가지로 분류할 수 있다(Figure 2).

- 이어플러그(earplug): 모든 군인은 반드시 자신에 귀에 맞 춘 이어플러그(custom fit earplug)를 착용해야 한다. 자신 에게 맞게 제작된 이어플러그는 적절한 착용감과 조건을 보장하기 위해 매년 적합성을 검사해야 한다. 예비 이어플 러그를 사용하여 이어플러그 장착을 시도한다. 잘 맞지 않 는 경우, 다른 유형의 이어플러그로 대체할 수 있다.

- 이어캡(ear-canal cap): $95 \mathrm{~dB}$ SPL 이하의 짧거나 간헐적 인 소음 수준 노출에 적합하며, 이어플러그나 이어머프만 큼 소음을 효과적으로 감쇠시키지는 못한다.

- 이어머프(ear muff): 소음감쇠에 효과적이며, 크기 조절이 가능하고, 연방 공급 시스템을 통해 제공된다. 이어머프에 전술 헤드셋을 추가로 장착할 수 있어 의사소통에도 효과 적이다. 또한 이어머프에 음향 필터를 교체할 수 있는 장점 이 있다. 그러나 일부 상황에서 의사소통이 비현실적이며, 제한된 공간 영역에서 만족스럽지 못하다는 단점이 있다.

- 헬멧(helmet): 머리보호 및 최대소음감쇠를 요할 때 사용 한다. 안전하게 고정 장치가 있고, 편안한 착용감과 적절한 소음감쇠가 가능하다.

\section{Hearing health education requirements}

청력프로그램 관리자(청능사)를 포함하여 청력프로그램 담 당자 및 청각기사는 연방규정 1910.95에 따라 군 청력프로그램

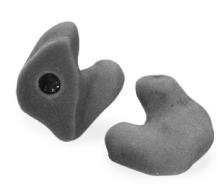

Earplugs

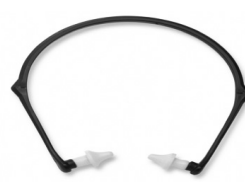

Ear canal caps

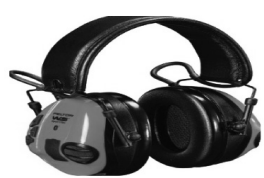

Noise muffs

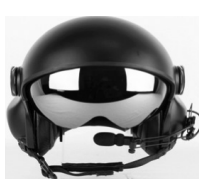

Helmet
Figure 2. Type of commercial hearing protectors. 
의 해당된 모든 군인과 소음에 노출 된 군무원에게 매년 보건 교육을 제공해야 한다. 교육은 매년 실시되는 청력검사와 더불 어 시행할 수 있다. 일시적 청력 손실의 기능에 미치는 영향을 포함하여, 청각에 소음의 영향과 청력보호장비의 목적, 장-단 점, 다양한 유형의 소음 감쇠, 청력보호장비의 사용과 훈련 기 간 동안 청력보호의 중요성을 교육한다. 또한 청력검사의 목적 과 필요한 청력검사의 종류도 설명해야 한다.

\section{Notification procedures for significant threshold shift}

미 연방 직업안전 환경보건국의 청력보존 소프트웨어에서 자 동적으로 유의미한 역치변동 여부를 표시할지 결정하고, 연령 보정 계산은 따로 적용되지 않는다. 유의미한 역치변동이 발생 하면, 군무원은 30 일 이내에 미 연방 직업안전 환경보건국의 청 력보존으로부터 추적 검사를 받아야하고, 군인은 90 일 이내에 후속 검사를 받아야 한다. 군인을 위한 후속 검사는 30 일이 아 닌 90일 이내에 받으면 되고 이는 군사 작전 임무를 지원하기 위해서이며, 추후 후속 검사를 위한 적절한 시간을 보장된다. 유의미한 역치변동이 두 번째 후속 청력검사에서도 확인되면 정기적인 청력의 완료일로부터 21일 이내 서면으로 군인 또는 군무원에게 알려지며, 군인의 부대 지휘관 또는 군무원의 직속 상관에 보고된다. 개인의 청력을 위한 맞춤 테스트는 두 번째 후속 청력검사 시, 청각기사 또는 청력프로그램 관리자에 의해 수행되어야 한다. 유의미한 역치변화가 미 연방 직업안전 환경 보건국의 청력보존의 청력검사에서 확인되면, 청각기사 또는 청력프로그램 관리자에게 추적 관찰을 받으며, 개인 기준 청력 검사를 다시 설정할 것이며, 미래의 청력검사 결과와 비교될 수 있는 새로운 기준을 만들 것이다.

다음과 같은 사항에 노출될 때 국방부지시(DODI.6055.12)에 따라, 청력보존에 등록된다.

- 20 16,000 Hz의 주파수 대역의 지속적이거나 간혈적인 소음이면서, 8 시간 $85 \mathrm{~dB}$ 또는 그 이상의 강도일 때

- 충격소음 음압이 $140 \mathrm{~dB}$ SPL Peak이거나 그 이상일 때

- 유해성 평가 혹은 특별한 측정을 요구하는 초음파의 소음 노출이 발생하는 특정 환경일 때

- 작업장에 이독성 노출이 의심될 때

이독성 노출이 직업적 노출 한계인 $50 \%$ 를 초과할 때 군 청 력프로그램에 등록이 필요하다. 직업적인 이독성 및 청력 손실 은 육군공중보건국의 웹 홈페이지에서 확인할 수 있다. 새로이 배치된 군무원은 가급적 빨리(초기 노출 후 30 일 이내) 기준청 력검사를 완료하게 된다. 모든 소음 노출 및 이독성에 노출된 군무원은 반드시 청력도뿐만 아니라 매년 후속 청력검사를 받 아야 한다. 유해한 소음이 있는 공간에서 근무 중 심도 이상의 난청을 가진 군무원은 반드시 기준 청력도와 최종 청력도를 받
아야 한다.

유의미한 역치 변화가 발생한 경우 필요한 후속 테스트를 정 부에서 허락받아 진행해야 되며, 6 개월 전에 검사를 받아 군인 이 전역 전 최소 6 주 전에는 최종 청력도를 받아야 한다. 복무 가 끝나기 6 개월 전에 완료되어 있다면, 군인과 군무원의 이미 완료된 정기적인 청력검사 결과를 최종 청력도로 사용될 것이 다. 최종 청력은 청력 보존을 담당하는 미 연방 직업안전국 환 경보건국에서 기입할 것이다. 또한, 청력프로그램관리의 설치 는 미 연방 직업안전국 환경보건국의 최종 청력검사가 정확히 되고 있는지를 보장하고 책임진다.

군인은 복무기간이 만료 시점에 가까울 때, 군 전역 시, 근무 분과가 바뀔 때(육군 $\rightarrow$ 해군), 군 구성군이 바뀔 때(현역 $\rightarrow$ 예비 군), 군무원의 직위 상태가 변화할 때에 최종 청력도가 필요하 다. 군무원 역시 더 이상 위험 소음이 있는 곳에서 일하지 않을 때, 고용상태가 끝날 때, 직위 상태가 변화할 때 최종 청력도가 필요하다.

\section{DISCUSSIONS}

높은 강도의 소형 화기, 폭발 장치의 사용, 또는 포병 사격 등 에 의해 발생된 소음성난청은 일회성의 결과일 수 있다. 그러나 청력에 위험한 소음에 무방비한 노출, 즉 군 부대에서 발생되는 대부분의 고강도의 소음이 청력보호장비 없이 군인들의 귀에 그대로 노출된다면 일시적인 청력 손실을 발생하기에 그 강도 가 다분히 크다. 전문가들은 초기의 일시적 역치변동이 어느 정 도 회복될 수도 있지만, 반복적인 잦은 노출로 이어진다면 영구 적 역치변동의 청력 손실로 나타날 수 있다고 경고한다(Kim, 2002). 특히 영구적인 청력 손실과 연관된 직접적인 외부적 증상 이 없고 초기 자각증세가 뚜렷하지 않으므로(Salmivalli, 1979), 수년에 걸쳐 점진적으로 발생되는 손실의 결과로 나타난다면 군인 또는 군무원들은 쉽게 소음성난청과 소음성이명의 위험 도를 인식하지 못하는 경우가 빈번하다. 더불어, 높은 강도의 소음 노출에 의한 내이의 손상은 이명을 유발할 수 있다. 청각 기관의 유해 소음에 대하여 적절치 못한 보호와 함께 스트레 스, 흡연, 알코올은 이명을 보다 악화시킬 수 있다. 과다한 소음 노출 후 경고 신호로서 일부 역할을 할 수 있지만 한 번 발생한 이명은 대부분 영구적이며 현재까지의 치료법으로는 이명이 완 치되기 어렵다(Sułkowski et al., 1999).

보호되지 않은 상태로 위험한 소음에 군인들의 청각기관이 지속적으로 노출됨으로써, 말소리를 분별하고 이해하는 데 필 수적인 어음주파수의 가청이 제한되며, 작업능력 및 삶의 질을 저하시키는 현저한 청력 손실을 야기한다. 시끄러운 청취 등 환 경, 군사 차량 및 항공기, 무기, 화재, 또는 전투상황 의사소통 
에서 청각은 더 제한되고, 그 손실은 통신과 임무에 영향을 미 칠 수 있다(Ylikoski \& Ylikoski, 1994). 영구적인 청력 손실에 대한 치료법은 현재까지 발견되지 않았지만, 충격 또는 지속적 인 소음 노출로 인한 청력은 효율적인 청력보호관리 시스템에 의해 일정 정도 예방될 수 있다. 또한 손상 후에도 남아 있는 잔 존 청력이 악화되지 않게 보호하는 것 역시 중요하다(Ylikoski, 1994). 이러한 소음 노출로 인한 난청 및 이명은 소음으로부터 멀어져서 충분한 휴식을 취하거나 적절한 청력 보호구의 사용 만으로 어느 정도 방지하거나 완화될 수 있다. 이를 위해서는 체계화된 청력보존프로그램이 전문가에 의해 만들어지고 체계 적으로 시행되어야 한다.

앞서 본문에서 살펴본 것처럼, 청각학 발전의 기원이 된 미국 의 군부대에서는 1960년대부터 군인들을 위한 군 청력프로그 램을 효율적으로 실시해오며 복무 중은 물론 전역 후에도 적절 한 청각적 관리와 보상을 실시해오고 있다(USACHPPM, 2004). 국내 역시, 개인용 또는 공용 화기를 이용한 사격 시, 소 음발생장소에서 근무할 경우 청력 손상을 방지하기 위하여 이 어플러그나 귀 덮개 착용을 문서화하고 있다. 개인 청력보호구 를 착용하고 작업 시 작업 간 의사소통이 제한될 경우에는 수 신호 등을 활용하여 보완하고 있다. 또한 군인에게 소음성난청 이 발생하였을 경우에는 요관찰자 혹은 유소견자로 구별하여 적절한 조치를 취하고 있다. 그러나 본문에서 소개한 미군에서 현재 시행되고 있는 체계화된 청력보존프로그램에 비하면 아 직 제도화되어 정착되어야 할 부분이 많이 있다. 또한 일반적으 로 사업체에 근무하기 전 젊은 나이에 의무적으로 장기간 군 복무를 해야 하는 국내의 군제도 상황을 고려한다면, 군에서의 소음 노출은 군기간 동안만의 문제가 아닌 추후 사업장에서 소 음 노출 근로자에 대한 청력관리 측면에서 문제 시 될 수 있으 므로 국가 차원의 적극적인 노력이 절실하다(Kim, 2014).

유모세포는 손상으로 인해 손실되고 나면 재생이 불가능하 기 때문에 그 치료에는 한계가 있다. 또한 개인에 따라 소음에 대한 민감도가 다르다는 것은 잘 알려져 있지만 그 민감한 정 도를 미리 검사할 수 있는 도구는 아직 없는 실정이다. 그러나 세계보건기구에 의하면 소음성난청의 절반 이상이 예방 가능 한 것으로 평가되고 있으며(WHO, 2013). 군 복무 시 경험한 소 음 노출은 사전에 보호될 수 있고 충분히 예방될 수 있다. 따라 서 예방책이 가장 중요한 소음성난청을 위해 소음에 노출되지 않도록 노력하고, 소음 노출을 피할 수 없는 현장에서는 소음 차폐 및 청력보호장비의 사용을 적극 활용하는 것이 무엇보다 중요하다. 특히 총기류를 다루는 군대에서 소음성난청에 대한 장교 및 군인들을 대상으로 한 교육의 실시와 적절한 보호장구 착용의 필요성을 알리는 것은 필수적이며 이를 위한 제도적 장 치와 사회적 관심이 지속적으로 필요하다(Shim, 2015).
중심 단어 : 군대 소음·군 청력프로그램·청력보존프로그램· 소음성난청.

\section{Acknowledgments}

본 논문은 미래창조과학부와 한국연구재단의 이공계 신진연구자 지 원사업(NRF-2014R1A1A1003132)으로부터 연구비를 지원받아 수 행되었습니다.

\section{REFERENCES}

Alberti, P. W. (1987). Tinnitus in occupational hearing loss: Nosological aspects. The Journal of Otolaryngology, 16(1), 34-35.

American National Standards Institute (ANSI). (1996). American National Standard: Determination of occupational noise exposure and estimation of noise-induced hearing impairment (ANSI S3.44-1996). New York: American National Standards Institute, Inc.

Axelsson, A. \& Hamernik, R. P. (1987). Acute acoustic trauma. Acta Oto-laryngologica, 104(3-4), 225-233.

Bohnker, B. K., Page, J. C., Rovig, G., Betts, L. S., Muller, J. G., \& Sack, D. M. (2002). U.S. Navy and Marine Corps Hearing Conservation Program, 1995-1999: Mean hearing thresholds for enlisted personnel by gender and age groups. Military Medicine, 167(2), 132-135.

Center for Hearing and Communication. (2014). Common environmental noise levels. Retrieved from http://chchearing.org/noise/common-environmental-noise-levels.

Collée, A., Legrand, C., Govaerts, B., Van Der Veken, P., De Boodt, F., \& Degrave, E. (2011). Occupational exposure to noise and the prevalence of hearing loss in a Belgian military population: A cross-sectional study. Noise and Health, 13(50), 64-70.

Department of the Army. (2015). Department of the Army Pamphlet 40-501: Army Hearing Program. Washington, DC: Department of the Army.

Gold, S., Attias, J., Cahani, M., \& Shahar, A. (1989). Hearing loss as a result of basic military training. Harefuah, 116(7), 377-379.

Halford, J. B. \& Anderson, S. D. (1991). Anxiety and depression in tinnitus sufferers. Journal of Psychosomatic Research, 35(4-5), 383-390.

Henselman, L. W., Henderson, D., Shadoan, J., Subramaniam, M., Saunders, S., \& Ohlin, D. (1995). Effects of noise exposure, race, and years of service on hearing in U.S. Army soldiers. Ear and Hearing, 16(4), 382391.

Hwang, S. H. \& Park, J. B. (2013). Daytime and night-time noise exposure assessment for soldiers at a military rifle range. Journal of Environmental Health Sciences, 39(4), 354-359.

Keim, R. J. (1970). Impulse noise and neurosensory hearing loss. Relationship to small arms fire. California Medicine, 113(3), 16-19.

Kim, H. J. (2002). Noise-induced hearing loss. In J. S. Kim, S. O. Chang, H. H. Lim, J. K. Lee, C. H. Lee, S. G. Wang, et al. (Eds). Otorhinolaryngology Head and Neck Surgery (pp. 690-697). Seoul: Ilchokak.

Kim, K. S. (2012). Noise and hearing. Paju: Idam Book.

Kim, K. S. (2014). Noise and tinnitus. Paju: Korean Studies Information.

Kim, K. S., Kim, J. H., \& Yoon, Y. H. (2012). The characterisitics of tinnitus and its relationship to depression from tinnitus acquired from military service. Korean Journal of Otorhinolaryngology-Head and Neck Surgery, 55(12), 757-763.

Kim, S. H., Lee, Y. H., Hwang, J. H., Oh, M. A., Lee, M, K., Lee. N. H., et al. (2014). Poilcy report: 2014 the disabled of survey. Korea Institute for Health and Social Affairs, 150-151.

Klockhoff, I., Lyttkens, L., \& Svedberg, A. (1986). Hearing damage in military service. A study on 38,294 conscripts. Scandinavian Audiology, 15(4), 217-222.

Le Prell, C. G., Henderson, D., Fay, R. R., \& Popper, A. N. (2012). Noise-induced hearing loss: Scientific advances. New York: Springer.

Lee, J. K., Chang, J. H., Ann, C. N., \& Cho, J. J. (1995). Prevalence of noiseinduced hearing loss and its related factors in men in their twenties 
with military duty-off. Korean Journal of Family Medicine, 16(6), 373380.

Salmivalli, A. (1979). Military audiological aspects in noise-induced hearing losses. Acta Oto-Laryngologica. 360(Suppl.), 96-97.

Shim, H. J. (2015). Noise-induced hearing loss. Hanyang Medical Reviews, 35(2), 84-91.

Sułkowski, W., Kowalska, S., Lipowczan, A., Prasher, D., \& Raglan, E. (1999). Tinnitus and impulse noise-induced hearing loss in drop-forge operators. International Journal of Occupational Medicine and Environmental Health, 12(2), 177-182.

US Department of Health and Human Services. (1998). Criteria for a recommended standard: Occupational noise exposure (pp. 1-122). Cin- cinnati, OH: National Institute for Occupational Safety and Health. USACHPPM (US Army Center for Health Promotion and Preventive Medicine). (2004). Retrieved from http://www.vi.ngb.army.mil/html/ safety/docs/Noise\%20in\%20. Army\%20Equipment.pdf.

World Health Organization (WHO). (2013). Deafness and hearing loss. Retrieved from http://www.who.int/mediacentre/factsheets/fs300/en/.

Ylikoski, M. E. (1994). Prolonged exposure to gunfire noise among professional soldiers. Scandinavian Journal of Work, Environment and Health, 20(2), 87-92.

Ylikoski, M. E. \& Ylikoski, J. S. (1994). Hearing loss and handicap of professional soldiers exposed to gunfire noise. Scandinavian Journal of Work, Environment and Health, 20(2), 93-100. 